\title{
Formulation and Verification of Standard Key Performance Indicators for a Design Department:
}

\section{A Study of In-House Designer Teams in Large Japanese Enterprises \\ デザイン組織の標準 KPI の策定と検証 \\ 一日本企業における社内デザイン組織を研究対象としてー}

\begin{abstract}
Rui Mao*1, Yuichi Washida*2
一橋大学 経営管理研究科

毛 鋭

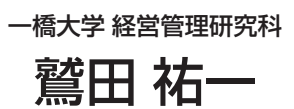

${ }^{* 1}$ School of Business Administration of Hitotsubashi University, Tokyo, Japan, bd191009@g.hit-u.ac.jp

${ }^{* 2}$ School of Business Administration of Hitotsubashi University, Tokyo, Japan, b101348r@r.hit-u.ac.jp

Abstract : The impact of dominant design on innovative performance and the introduction of Design Driven Innovation are examples of the wide recognition of the strategic and crucial roles of design in boosting a firm's competitiveness. This role has been changing and evolving beyond traditional design. However, despite this trend, it has been pointed out that the potential of design resources, including in-house designers, is often not sufficiently utilized in Japanese enterprises. It is reasonable to assume that this issue stems from visualization of design values. Therefore, the aim of this study is to develop and verify standard key performance indicators that can evaluate the activities and outcomes of in-house design teams quantitatively. This may contribute to effective utilization of design resources. In the study, 465 managers from four large Japanese enterprises responded to a survey of multisource assessment of the performance of in-house designer teams. Principal component analysis revealed five important factors: product development capabilities, provision of information, brand consistency, output speed, and costs of evaluation of the performance of the design department. Multiple regression analysis indicated that the emphasis on KPIs for design departments differs among enterprises.
\end{abstract}

Keyword : Corporate resources, Design values, Visualization, Design-driven management

要約 : 本研究の目的は, 社内のデザイン組織の活動や成果を共通的な視点で定量的に評価できる手法を開発することを通じて, デザイン経営における「デザイン価值の可視化」問題を明らかにし，デザイン資源の有効活用に寄与することである。そこで, 本研究は実務的な視点から，日本大手企業 4 社のデザイン組織を対象に，プロジェクト単位で合計 465 名の社内他部門の中間 管理層によるデザイン組織へのパフォーマンス評価を求めて, 社内デザイン組織は事業へ貢献する主な要素を「商品開発力」. 「情報の提供」「「ブランドの一貫性」「「アウトプットの速度」および「コスト」, という五つの要素に抽出することができた。そ の上, 重回帰分析を用いて，それがデザイン組織への満足度に与える影響性を考慮し検証したところ，各社には社内デザイン組 織への評価あるいは求めるポイントは異なることがわかった。分析結果を受けて, 各企業におけるデザイン組織のパフォーマン スを定量的に評価する指標が策定できることを示唆した。

キーワード : 経営資源, デザイン価值，可視化，デザイン経営

Information : Received 16 August 2021; Accepted 10 October 2021; J-STAGE Advance published 11 February 2022

\section{I. 研究背景}

日本では, 1950 年代後半から輸出品デザイン法の制定
やグッドデザイン賞の創立などのデザイン政策を打ち出 し, デザイン力の向上を目的とした様々な取り組みを展 開し始め, 推進してきた。その後, 2000 年代に入ってか ら,「戦略的デザイン活用研究会」の設置と『競争力強化 
に向けた 40 の提言』の公表はデザインの役割を戦略的 な位置付けに昇格させ, デザインの重要性への再認識を 促した。さらに, 経済産業省・特許庁は 2018 年に画期 的な『デザイン宣言』を発表し，デザインをブランド構 築とイノベーションに資する重要な経営資源として捉え 直し「デザイン経営」を企業の競争力を強化するための 経営手法として使いこなし，適切なマネジメントを実施 していく重要性を訴えている。要するに，国では，従来 からデザインの重要性を認識しており, 産業界への浸透 や企業競争力の強化に寄与することを期待しデザイン政 策を推進している。

このような状況の中, 経済産業省が公表した調査結果 によると，デザインが事業運営や売上に貢献していると 回答している企業は 8 割超などの結果が示され，企業に おけるデザインの重要性は高まっていると捉えられる (Ministry of Economy, Trade and Industry, 2016)。また, 同書では，企業はデザインの役割はブランドの構築や外 観での付加価值の向上など, 多様な役割の変化と拡大を 期待していることが提示された。それに伴い，デザイン 部門の役割も変化していると言及した。それに，特許庁 による報告書では，産業世代の交代にもかかわらず，デ ザインの川上化のようにデザインが果たす役割は拡大し て扔り，企業経営に扔ける重要性が増していることが言 及された（Japan Patent office, 2018)。同書ではデザイン 重視の 26 社を調查した結果, デザイン風土の社内浸透 や経営に近いデザイン組織の位置付けなど重要性は認識 されていると示した。

ところが，日本では「デザイン」に対する理解と認識 は欧米に比べ狭義であり，企業においてインハウスデザ イナーを含めたデザイン資源が活用されていないのが現 状である (Ministry of Economy, Trade and Industry, 2014）。それに加え，世界の有力企業が戦略の中心にデ ザインを据えている中，日本では全体的にデザイン経営 を導入している企業は限定的で，グローバル競争での弱 点になっているという指摘も存在する (Japan Patent office, 2018)。それに，デザイン経営の導入が遅れている原因 に関して, 全社的な意識の不統一や経営陣の理解不足拀 よびデザインの効果が定量化できない問題などが取り上 げられている (Ministry of Economy, Trade and Industry, \&
Japan Patent office, 2018)。総じて, 日本企業全体が「デ ザイン」を資源として扱い，デザイン経営の必要性を認 識できることは問題視されている。その課題を解決する ために, デザインの価值を可視化することが必要である。

そこで, 企業経営におけるデザイン価值の可視化問題 にあたって，様々な試みが行われている。例えば，製造 業に扔けるデザインを重視する企業とそうではない企業 の収益率の比較研究 (Walsh \& Roy, 1985) ; 企業の財務業 績とデザインの関係性に関する調査（Benedict, Hugo, Garen, \& Fabricio, 2018）などが挙げられる。ところが, デザインの価值に対する客観的な評価指標の必要性は従 来から唱えられてきたにもかかわらず, 統一された説得 力のある評価指標はまだ存在しないと指摘された (Washida, 2014)。特に，企業の社内デザイン組織の活動 評価に対する標準化された評価基準は検証されていない と見られる。

では，なぜ社内デザイン組織の活動を定量的に評価す べきなのかという疑問が浮かぶかもしれない。その原因 は主に三つある。まず，日本におけるデザインを取り巻 く環境として, フリーランスデザイナーと比ベてイン八 ウスデザイナーが占める割合が多い。要するに，イン八 ウスデザイナー制度が普及しているものの, 社内のデザ イン組織は他の職能部門（例：営業部門）と比べて組織 活動の成果が量的に評価しにくいため, デザイン価值の 可視化の課題が従来から存在する。そして, 社内デザイ ン組織の活動評価が実現しにくいことは, 企業経営にお けるデザイン人材の確保やデザイン機能の事業貢献度の 明示に影響を及ぼす。それに加え, デザイン経営を促進 するために，デザイン組織の活動を共通的な視点で評価 し定量化できる手法の開発が必要とされる。

したがって, 本研究の中心課題としては, 社内のデザ イン組織の活動と成果を如何に定量的に評価し，デザイ ン機能が企業経営に与える貢献度を如何に可視化にする かということである。その上, 本研究では, 社内のデザ イン組織の活動や成果を共通的な視点で定量的に評価で きる手法を開発することを通じて, デザイン経営におけ る「デザイン価值の可視化」問題を明らかにし, デザイ ン資源の有効活用に寄与することを目指す。 


\section{II. 既存研究レビュー}

\section{1. ドミナント・デザイン論}

「デザイン経営」の定義が示したデザインをイノベー ションに資する経営資源という捉え方のように，企業経 営におけるデザインの重要性はUtterback（1994）, Utterback et al.（2006）の「ドミナント・デザイン」理 論から窺える。

Abernathy（1978）と Abernathy and Utterback（1978） に提起されて以来, ドミナント・デザイン論はイノベー ション研究の中核モデルの一つとして脚光を浴びており, 様々な産業界においてドミナント・デザインの存在や影 響が検証されてきた。先行研究によると，「ドミナント・ デザイン」とは, 技術的な可能性と市場選択の相互作用 によって生まれるものであり（Utterback, 1994），4 年連 続して 50 \% 以上の市場シェアを獲得したデザイン (Anderson \& Tushman, 1990) のことを指しおり，かつあ る製品カテゴリーにおいて製品提供者はその製品を投入 する際に，それに従わないと市場に受け入れられないデ ザイン方式である（Abernathy, 1978; Christensen, Suarez, \& Utterback, 1998; Suarez \& Utterback, 1995; Utterback \& Suarez, 1993)。それに, 代表的な提唱者である Utterback （1994）によると，ドミナント・デザインは必ずしも技 術決定論に従うような科学的ないし技術的に最先端的 （技術パフォーマンスがいい）なものではなく，市場での 利害関係者の相互作用によって生み出されるものである (Anderson \& Tushman, 1990; Utterback, 1994)。また， そ れは技術的，社会的，政治的な要素によって生まれた妥 協的なものであり，各個人や組織または組織に関係する ネットワークが形成するものであると理解されている (Anderson \& Tushman, 1990)。

他方，ドミナント・デザインが現れると，急進的なプ ロダクト・イノベーションの発生頻度は低くなる一方で, 既存製品の改良をはかる漸進的なプロダクト・イノベー ションや生産プロセスの改善や精緻化をはかる漸進的な プロセス・イノベーションの発生頻度が高まる (Abernathy \& Utterback, 1978)。また, それの出現に伴い, 規模の経 済が作用するようになる。さらに, 当該製品にネットワー
ク外部性が動く際に，その影響性はより一層大きくなり， 競争者の数は著しく減る結果になると指摘されている (Suarez \& Utterback, 1993)。それに加えて，ドミナント・ デザインの出現は新技術を採用して大量生産することの 前提条件であり，ただ単にイノベーションが普及する方 法だけではないとその重要性が強調されている(Anderson \& Tushman, 1990)。そのため, ドミナント・デザインは 技術の進化において重要な分岐点であり, その出現は技 術的な不確実性を解消できると捉えられる。

そこで，ドミナント・デザイン論が示しているのは, デザインは技術進化と市場競争に関連する重要な経営要 素であり，場合によっていいデザインの創出は優れた新 技術によって得た効果と比べてより企業に競争優位性を もたらすことができるということだと考えられる。

\section{2. デザイン・ドリブン・イノベーション}

ドミナント・デザイン論と同様に, デザインをイノベー ションの生起を促進できる資源と見なす理論として, Verganti（2009, 2016）が提唱する「デザイン・ドリブ ン・イノベーション」(design-driven innovation) が挙げ られる。この理論において, Verganti $(2009,2016)$ はデ ザインがイノベーションに与える独自の貢献を強調して 焦点を絞り，デザインの定義を「モノに意味を与えるも のである」(design as making sense of things）としてい る。この定義に従うと, デザインは意味を刷新し, 意味 は市場での差別化をもたらすことや企業の競争優位を生 み出すことにつながるため, デザインは競争において極 めて重要であると明らかにされた。さらに, Verganti （2009）はデザインによる意味のイノベーションがあら ゆる産業において競争を決定づける不可欠な要素である と強調した。

その上, Verganti $(2009,2011)$ は意味のイノベーショ ンを漸進的な次元と急進的な次元という二つの次元から 成り立つものであると示した。その中，急進的な意味の イノベーション（radical innovation of meanings）はデザ インで創り出された新しい意味によって駆り立てられる イノベーションであり，企業は製品が有する意味や製品 言語に画期的革新を施すことによって，消費者に新しい ビジョンを提供するプロセスであると捉えられる。これ 
こそが, Verganti (2009, 2011, 2016）が唱える「デザ イン・ドリブン・イノベーション」(design-driven innovation）もしくは「デザイン・プッシュ」（design push) である。

これで, Verganti $(2009,2011)$ はイノベーションを 「パフォーマンス」(技術) と「意味」(製品言語) という 二つの軸を用いて整理し, 上記のデザイン・ドリブン・ イノベーションに加えて, 市場やユーザーによって駆動 される「マーケット・プル・イノベーション」と技術に よって駆動される「テクノロジー・プッシュ・イノベー ション」という三つのイノベーション戦略をモデル化し た。その中，前者はデザインのプロセスにおいてデザイ ナーによって創出されたものとされるゆえ，新しい意味 はイノベーションの源泉であると理解できる。言い換え ると，デザインという行為もしくは活動はイノベーショ ンの源泉であり，イノベーションの創出を左右できると 考えられる。それに, Verganti（2009）は任天堂が開発 したWii ゲーム機の事例を取り上げて,「技術のエピファ ニー」（technology epiphany）の存在を提示し，技術とデ ザインの関係について言及した。そこで，デザインの価 值または役割は産業発展の初期段階にとどまらず，画期 的な技術が出現した時にも重要であると明示された。

総じて，デザイン・ドリブン・イノベーションの本質 としては，デザインは企業や産業にとって技術の躍進と 同様な影響力を持つ決定的な資源であり，従来の捉え方 を見直し，より重要な戦略的位置付けに昇格させるべき だ考えられる。

\section{3. その他の企業経営におけるデザインの役割およびデ ザイン導入の効果}

Hayes（1990）は四つの側面から企業経営におけるデ ザインの役割を論じた。いわゆる，生産コストの低減や 商品の品質や信頼性の向上および商品開発リードタイム の短縮を促進できる「競争力を強化する」(facilitator) 役 割 ; (2)市場シェアの増加やブランドの構築などに優位性 を転換できる「差別化の要素」(differentiator) とする役 割; 商品開発における各職能部門間の統合を促す「統合」 (integrator) の役割；および(4)企業のイメージ，価值観 やブランドなどの「情報を伝達する」(communicator) 役
割である。

日本企業でのデザイン経営の取り組みにあたって， Nakamura（2007）は日本自動車産業におけるデザインの 歴史を概観し，日産自動車の実例を取り上げながら，経 営トップによるデザインへの積極的な取り組み（例えば, 専門的なデザイン責任者の設置またはデザインへの投資 など）の必要性とデザイン機能がもたらすブランド一貫 性やブランド構築への貢献などを提示し, 経営資源とし てのデザインの重要性を示唆している。その他, Odajima （2007）は NTT 社の事例を提示しながら, デザインが企 業のアイデンティティ戦略あるいはブランド力構築の実 現にあたって果たす役割を言及している。

いずれにせよ，今までの研究ではデザインが企業経営 に寄与する重要な資源であることには整合していると突 える。ところが，数多くの研究は商品のデザインそれ自 体がもたらす貢献または価值を議論しており, 社内のデ ザイン組織およびその貢献を対象とする研究はあまりさ れていないと見える。なお，デザイン組織を評価する際 には主に消費者を調査対象者とする場合が多く，それは デザイン組織へのパフォーマンス評価においてわずかの 一部に過ぎない考えられる。したがって，本研究では， 社内のデザイン組織に焦点を絞り, 多面的・複合的な視 点で社内デザイン組織の活動や成果を考察し, 定量的か つ標準的な評価基準があるかどうかを探索したい。

\section{III. 研究設計}

\section{1. 調査内容}

本研究においては, 実務的な視点から大きい会社での デザイン部門のパフォーマンスをプロジェクト単位で会 社の他部署に評価を求めることによって, デザイン部門 の社内位置付けとデザイン機能の貢献度を検証する。

上記の先行研究と参加企業の実務経験を踏まえて, 本 研究では概ね「デザインによる商品の価值向上への貢献」 を代表とする 7 つ側面から質問項目を設定し， 5 件法 を用いてデザイン部門の活動・成果に対して満足度評価 を求める。さらに, 社内デザイン部門の業務に対して総 合満足度評価も 5 件法で求めた。 


\section{2. 調査対象とデータ収集}

本研究では，上述の質問項目を用いた上で，過去一年 間に社内のデザイン部門と共同に業務を行った他部署に 対して，行われた業務・案件の活動実績に基づき，デザ イン部門への評価を求めることとする。なお，本研究に おいては該当する社内の他部署の部署長・部門長，いわ ゆる中間管理層を被験者として調查を実施した。

中間管理層を選定した理由は概ね三つある。まず，本 研究は実務経験に基づいて社内のデザイン部門のパ フォーマンスを評価することを目的として設定している。 すなわち，実務をベースとした本研究ではデザイン部門 という社内の組織に対する一般的なイメージではなく， 実際に協働活動を実施した他の事業部からの評価を求め たいため，事業部のリーダーとしての中間管理層たちは 現場の仕事に精通しながらも経営者目線で事業または業 務の進渉や状況を把握できる役目であり，彼らに評価を 求めるのは適切である。それに，各部門に所属する一般 従業員ではなく，部門長をはじめとする中間管理層を選 定したもう一つの理由は, 本研究で最終的な評価対象は デザイン部門を中心とする部門間の関係ということにあ る。それゆえ，業務遂行や成果評価などを含めた部門管 理を統括する役割を担う中間管理層は部門の代表として デザイン部門への評価をすべきである。それに加えて， 本研究では業務や事業に携わった部門と部門間の評価に 焦点を絞っており，協働活動に参加したデザイナーへの 評価，いわゆる個人に対する評価ではないように設定し ているため，業務や事業の全体像を把握している中間管
理層に評価してもらうことは妥当であると見られる。 その上で, 本研究では日本国内の大手企業 4 社に社内 アンケート調査の実施を依頼した。2020 年 10 月から 2021 年 2 月にかけてデー夕収集を行った結果, $\mathrm{A}$ 社が 134 件, B 社が 136 件, C 社が 115 件，D社が 80 件で合 計 465 件の有効回答を集めた。

\section{3. 分析手法}

収集したデー夕に基づいて，社内デザイン組織のアウ トプットへの評価に関する 7 つ質問項目に対して探索 的因子分析を実施した。因子分析の結果をもとに，デザ イン組織の評価にあたって高い説明力を持つ要素を抽出 する。その上, 導出された要素を説明変数にし, 社内デ ザイン組織への総合満足度評価を従属変数として重回帰 分析を実施し, 社内デザイン組織の貢献と社内他部門に よる満足度評価との関係性を検証した。分析には SPSS Statistics 26 を用いた。

\section{IV. 研究結果}

因子分析の結果により，[Q1_3] ・ [Q1_1]・[Q1_2] を 因子 I， ［Q1_4］を因子 II，［Q1_5］を因子 III， [Q1_6] を因子 IV， [Q1_7］を因子 V に抽出することができる。 また，それぞれの要素を「商品開発力」(因子 I), 「情報 の提供」(因子 II),「ブランドの一貫性」(因子 III)，「ア ウトプットの速度」（因子 IV）䇽よび「コスト」（因子

\begin{tabular}{|c|c|c|c|c|c|c|}
\hline & 項目 & I & II & III & IV & $\mathrm{V}$ \\
\hline$\overline{\text { Q1_3 }}$ & デザイン視点での商品力および訴求力向上サポート & .781 & .020 & .158 & .328 & .236 \\
\hline Q1_1 & デザインによる商品の価值向上への貢献 & .777 & .198 & .366 & .083 & .015 \\
\hline Q1_2 & 製品・サービスに関する企画・提案（新製品・新機能） & 684 & .445 & .022 & .052 & .320 \\
\hline Q1_4 & 将来のビジョン提案, ユーザー情報トレンド情報の提供 & .196 & .906 & .147 & .199 & .157 \\
\hline Q1_5 & ブランドとしての一貫性確保 & .254 & 128 & .917 & .113 & .172 \\
\hline Q1_6 & アウトプット納品までのスピード & .209 & .202 & .112 & .909 & .217 \\
\hline Q1_7 & 貢献に対するコスト & .226 & .191 & .187 & .243 & .886 \\
\hline 固有佔 & & 3.657 & 0.808 & 0.66 & 0.597 & 0.479 \\
\hline 寄与率 & & 26.85 & 16.473 & 15.265 & 15.08 & 14.913 \\
\hline 累積寄 & 与率 & 26.85 & 43.323 & 58.588 & 73.668 & 88.581 \\
\hline
\end{tabular}




\begin{tabular}{llll}
\hline & \multicolumn{3}{c}{ 四社総合 } \\
\cline { 2 - 4 } & $\mathrm{B}$ & 標準誤差 & ベータ \\
\hline 説明変数 & & & \\
商品開発力 & 0.630 & 0.065 & $0.478^{* * *}$ \\
情報の提供 & 0.033 & 0.040 & 0.035 \\
アウトプットの速度 & 0.050 & 0.041 & 0.052 \\
ブランドの一貫性 & 0.051 & 0.042 & 0.053 \\
$\quad$ & 0.138 & 0.042 & 0.150 *ネト \\
\hline$R^{2}$ & $0.425^{\text {*** }}$ & & \\
\hline
\end{tabular}

従属変数：当該期間の活動に対する総合的な満足度評価 $* p<.05, * * p<.01, * * * p<.001$

\begin{tabular}{|c|c|c|c|c|c|c|c|c|c|c|c|c|}
\hline & \multicolumn{3}{|c|}{$A$ 社 } & \multicolumn{3}{|c|}{$B$ 社 } & \multicolumn{3}{|c|}{$\mathrm{C}$ 社 } & \multicolumn{3}{|c|}{$\mathrm{D}$ 社 } \\
\hline & $\mathrm{B}$ & 標準誤差 & ベータ & $\mathrm{B}$ & 標準誤差 & ベータ & B & 標準誤差 & ベータ & $\mathrm{B}$ & 標準誤差 & ベータ \\
\hline \multicolumn{13}{|l|}{ 説明変数 } \\
\hline 商品開発力 & 0.577 & 0.093 & $0.496^{* *}$ & 0.213 & 0.168 & 0.132 & 0.769 & 0.076 & $0.672^{* *}$ & 0.465 & 0.134 & $0.437^{* *}$ \\
\hline 情報の提供 & 0.112 & 0.067 & 0.126 & 0.236 & 0.106 & $0.186^{*}$ & 0.120 & 0.051 & $0.128^{*}$ & 0.085 & 0.077 & 0.124 \\
\hline アウトプットの速度 & 0.151 & 0.065 & $0.167^{*}$ & -0.033 & 0.093 & -0.026 & 0.080 & 0.053 & 0.086 & -0.079 & 0.082 & -0.111 \\
\hline ブランドの一貫性 & 0.067 & 0.075 & 0.067 & 0.110 & 0.087 & 0.113 & -0.109 & 0.053 & $-0.107^{*}$ & 0.139 & 0.087 & 0.205 \\
\hline コスト & 0.105 & 0.060 & 0.125 & 0.386 & 0.088 & $0.375^{* *}$ & 0.139 & 0.062 & $0.137^{*}$ & 0.063 & 0.084 & 0.096 \\
\hline$R^{2}$ & \multicolumn{3}{|c|}{$0.611^{* * *}$} & \multicolumn{3}{|c|}{$0.412^{* * *}$} & \multicolumn{3}{|c|}{$0.706^{* * *}$} & \multicolumn{3}{|c|}{$0.435^{* * *}$} \\
\hline
\end{tabular}

従属変数：当該期間の活動に対する総合的な満足度評価 $* p<.05, * * p<.01, * * * p<.001$

V)と名付けた。

その上, 上記の五つの要素, いわゆるデザイン組織パ フォーマンスを評価する指標が如何にデザイン組織への 社内満足度に影響を及ぼすのかを重回帰分析で検証した ところ, 調査対象者の 4 社から総合的に見ると「商品開 発力」 $(\beta=0.478, p<.001)$ と「コスト」 $(\beta=0.150, p<.01)$ という二つの要素は最も重要であることが判明した（表 2)。さらに, 参加 4 社の企業ごとの差異を検証するため に，導出された $5 つ の$ 要素に基づいて重回帰分析を行っ た。結果を表 3 に示す。

\section{V. 結論と考察}

本研究では, 社内のデザイン組織を対象に, 社内他部 門の中間管理層によるデザイン組織への満足度評価を求 めて，社内デザイン組織は事業へ貢献する主な要素を抽
出した上で，それがデザイン組織への満足度に与える影 響性を考慮し検証した。分析結果を受けて，各企業にお けるデザイン組織のパフォーマンスを定量的に評価する 指標が策定できると結論づけられる。

上節の分析結果を見ると, 導出された 5 つの要素の中 で, 調査対象者の四社は共に「商品開発力」と「コスト」 を重視するにもかかわらず，各社には偏りが存在すると 見られる。B社では「コスト」を最も重視するに対して, $\mathrm{A}$ 社と $\mathrm{C}$ 社では「商品開発力」に最も重きを置くと捉え られる。それに, $\mathrm{A}$ 社においては「商品開発力」と「ア ウトプットの速度」が重視されるに対して, B 社では「コ スト」と「情報の提供」が最も重視されることが見られ る。その一方で, C 社では「商品開発力」「コスト」にと どまらず，「情報の提供」も重んじるため， C 社は調査対 象社 4 社の中で, 最も総合的かつ全面的に社内デザイン 組織の貢献する要素を捉える会社であると考えられる。 ところが，C社の調査結果により，「ブランドの一貫性」 
は満足度評価に負の影響を与えることが検証されたゆ え，C社に扔いては「ブランドの一貫性」に抵抗感があ ると捉えられる。それに加え， $\mathrm{D}$ 社では「商品開発力」 のみに重きを置き，4社の中で一つの影響要素に専念す る唯一の会社であると見られる。言い換えれば，D社で は「商品開発力」が何よりも優先されると考えられる。

概して言えば，社内デザイン組織への評価あるいは求 めるポイントは企業ごとに異なるが，共通するところが 存在すると考えられる。要するに，導出された 5 要素の 全てが社内デザイン組織への満足度評価に影響を及ぼす ことではなく，四社では満足度評価に影響する共通要素 は「商品開発力」と「コスト」である。したがって, 組 織構造や規模に関わらず，各企業におけるデザイン組織 のパフォーマンスを共通的な指標で評価できると考えら れる。

また，社内デザイン組織が事業に貢献する五つの要素 の中で,「ブランドの一貫性」より「商品開発力」や「コ スト」への期待が高いという結果を踏まえて，社内デザ イン組織に求める貢献には「ブランドの一貫性」の重要 性は認識されているものの，実際にそれを肝要な評価基 準として社内のデザイン部を評価している会社はなかっ たと見受けられる。要するに，日本企業のデザイン部は ブランドに対して評価も期待もされて扔らず，ブランド の一貫性は企業経営において重要性を持つことが理解さ れているとはいうものの, 実際にはそれが求められず重 視されていないと考察できる。一方，ブランド一貫性に 関して，社内のデザイン組織は全然貢献できていないと いうニュアンスを汲み取れる。さらに，本研究の調查委 対象社は各業界において強いデザイン部門を持つ代表と する企業であるため, インハウスデザイナー制度を特徴 とする日本企業は全体的にこの傾向を持つのであろうと 考察できる。

その一方, 本研究のインプリケーションは三つある。 まず, 企業経営において, 自社のデザイン組織のパフォー マンスを高めること，または最終的に企業パフォーマン スを向上させることを目指す場合，本研究はある意味で 企業が取り組んでいくべき方向性を明らかにした。また， KPI 測定の結果を用いて競合他社と比較することによっ て，自社の足りないところを洗い出すことまたは優位性
をさらに強化することができるよう，企業戦略の見直し が可能になる。最後に，KPI に基づいてデザイン組織へ の満足度を高めることで, 社内におけるデザイン価值の 可視化とデザイン経営の浸透は実現可能となり, 企業競 争力の強化を促進できると考えられる。

\section{VI. 限界と今後の課題}

本研究には，多くの課題が残されているが，ここでは 主な 2 点を指摘する。1つ目は, 重回帰分析結果の精 度についてである。総合 4 社の決定係数（ $\mathrm{R}^{2}=0.425$, $\mathrm{p}<.001) ） の$ 説明力は高いとは言い難いものの, 有意性 検定に関して良い結果を示したゆえ，分析結果の妥当性 に関しては一定の成果を収めたと見受けられる。この結 果の原因については 4 社別の重回帰分析の結果を踏まえ て考察できる。要するに, 調查対象社の 4 社においては 社内デザイン組織に求めるポイントは企業ごとに大きく 異なるため, 総合的に判断する際には精度が下がるとい うことである。よって, 経営体質違いの多様な企業をもっ と増やせば，重回帰分析の精度が上がっていくと予想で きる。

2 つ目は測定尺度である。本研究では先行研究と企業 の実務経験に基づいて社内デザイン組織のアウトプット をまとめた上で検証を行った。ところが，社内デザイン 組織またはデザインが企業経営に貢献できるところは決 してこの 7 つ側面に限らず，それ以外にもあるだろう と考えられる。それゆえ，今後は他にも活かせる指標を 網羅し，検証に取り入れようと考えている。さらに，網 羅性と安定性を備えた KPI を用いて社内デザイン組織へ の評価に対して事業部ごとにどのような差異があるのか を検証していきたいと考えている。

\section{References}

Abernathy, W. J. (1978). A general model: Innovation and process change in a productive unit. In The productivity dilemma: Roadblock to innovation in the automobile industry. Baltimore: Johns Hopkins University Press.

Abernathy, W. J., \& Utterback, J. M. (1978). Patterns of industrial innovation. Technology Review, 80(7), 40-47.

Anderson, P., \& Tushman, M. L. (1990). Technological 
discontinuities and dominant designs: A cyclical model of technological change. Administrative Science Quarterly, 35(4), 604-633.

Benedict, S., Hugo, S., Garen, K., \& Fabricio, D. (2018). The business value of design. McKinsey \& Company, October. Retrieved from https://www.mckinsey. com/businessfunctions/mckinsey-design/our-insights/the-business-valueof-design (November 20, 2020).

Christensen, C. M., Suarez, F. F., \& Utterback, J. M. (1998). Strategies for survival in fast-changing industries. Management Science, 44(12-part-2), S207-S220.

Hayes, R. H. (1990). Design: Putting class into "World - Class". Design Management Journal (Former Series), 1(2), 8-14.

Japan Patent office. (2018). Design ga kigyou no kokusai kyousouryoku ni ataeru eikyou nado ni kannsuru tyousa houkokusyo. Japan Patent office, March. Retrieved from https://dl.ndl.go.jp/info:ndljp/pid/11515195 (November 25, 2020). (特許庁 (2018).「デザインが企業の国際競争力に与 える影響等に関する調査報告書」『特許庁』) (In Japanese)

Ministry of Economy, Trade and Industry. (2014). Kokusai kyousouryoku kyouka no tame no design thinking wo katsuyou sita keiei jittai tyousa houkokusyo. Nomura Research Institute, March. Retrieved from https://iss.ndl.go.jp/books/ R100000002-I025780936-00 (November 25, 2020)。(経済産業 省 (2014).「国際競争力強化のためのデザイン思考を活用 した経営実態調査報告書」『野村総合研究所』 3 月) (In Japanese)

Ministry of Economy, Trade and Industry. (2016). Hesei 27 nenndo waga kuni keizai syakai no jyouhouka \& saabisuka ni kakawaru kiban seibi (design no katsuyou ni yoru innovation sousyutsu kannkyou seibi ni muketa dezaingyou no jittai tyousa kenkyu) houkokusyo. Ministry of Economy, Trade and Industry, March. Retrieved from http://www.meti.go.jp/ meti_lib/report/2016fy/000998.pdf (November 25, 2020). (経済 産業省（2016）。「平成 27 年度我が国経済社会の情報化・ サービス化に係る基盤整備（デザインの活用によるイノベー ション創出環境整備に向けたデザイン業の実態調査研究) 報告書」『経済産業省』) (In Japanese)

Ministry of Economy, Trade and Industry, \& Japan Patent office. (2018). Design driven management senngenn. Ministry of Economy, Trade and Industry, \& Japan Patent office, May 23. Retrieved from https://www.meti.go.jp/press/2018/05/ 20180523002/20180523002-1.pdf (November 25, 2020).（経済 産業省・特許庁 (2018)。「『デザイン経営』宣言」『経済産 業省・特許庁』5 月 23 日）(In Japanese)

Nakamura, S. (2007). Design as corporate resource: Design management within the automotive industry. Hitotsubashi Business Review, 55(2), 26-35.（中村史郎（2007）。「経営資 源としてのデザイン一自動車産業におけるデザインマネジ メント (特集 デザインと競争力)」『一橋ビジネスレ ビュー』55(2), 26-35) (In Japanese)

Odajima, K. (2007). Design as identity strategy: A practical study of the brand identity strategy for NTT DoCoMo. Hitotsubashi Business Review, 55(2), 48-61. (小田嶋孝司（2007)。「アイ
デンティティ戦略としてのデザイン一NTT DoCoMo のブラ ンド・アイデンティティ戦略（特集 デザインと競争力）」 『一橋ビジネスレビュー』55(2), 48-61) (In Japanese)

Suarez, F., \& Utterback, J. (1993). Patterns of industrial evolution, dominant designs, and firms' survival. Research on Technological Innovation, Management and Policy, 5, 47-87.

Suarez, F. F., \& Utterback, J. M. (1995). Dominant designs and the survival of firms. Strategic Management Journal, 16(6), 415430.

Utterback, J. M. (1994). Mastering the dynamics of innovation. Boston, MA: Harvard Business School Press.

Utterback, J. M., Ekman, S., Sanderson, S. W., Vedin, B. A., Verganti, R., Tether, B., \& Alvarez, E. (2006). Design-inspired innovation. London, UK: World Scientific.

Utterback, J. M., \& Suárez, F. F. (1993). Innovation, competition, and industry structure. Research Policy, 22(1), 1-21.

Verganti, R. (2009). Design driven innovation: Changing the rules of competition by radically innovating what things mean. Boston, USA: Harvard Business Press.

Verganti, R. (2011). Radical design and technology epiphanies: A new focus for research on design management. Journal of Product Innovation Management, 28(3), 384-388.

Verganti, R. (2016). Overcrowded. Cambridge, USA: MIT Press.

Walsh, V., \& Roy, R. (1985). The designer as 'gatekeeper' in manufacturing industry. Design Studies, 6(3), 127-133.

Washida, Y. (2014). Design conveys innovation: Exploring new management strategy with power of design. Tokyo: Yuhikaku. (熟田祐一 (2014).『デザインがイノベーションを伝える： デザインの力を活かす新しい経営戦略の模索』有斐閣) (In Japanese) 